mental health facilities (Can J Psychiatry 2012;57[2]:Insert 1-6). Today, there are just 10653 beds (www.who.int/mental _health/evidence/atlas/profiles/can_mh _profile.pdf).

Over essentially the same time period, the number of incarcerated Canadian adults has leapt to 140 per 100000 population (www.statcan.gc.ca /pub/85-002-x/2012001/article/11715 -eng.htm\#a3) from 80 per 100000 (www .csc-scc.gc.ca/text/pblct/forum/e123 /e123h-eng.shtml).

But transinstitutionalization isn't the sole factor at play in the disproportionate incarceration of the mentally ill, several experts say. They point to Prime Minister Stephen Harper's "get-tough-on-crime agenda" as also having had a substantial impact on the numbers of incarcerated.

Statistics Canada indicates that roughly 38000 offenders were in federal or provincial jails on any given day in fiscal 2010/11 (www.statcan.gc .ca/pub/85-002- $x / 2012001 /$ article/11715 -eng.htm). That represented a $1 \%$ increase over the previous fiscal year and roughly a $5 \%$ increase over the course of a decade. It resulted in Canada being ranked 17th in incarceration rates among 34 Organisation for Economic Co-operation and Development member nations.

A disproportionate share of the men- tally ill are represented in those who've been caught up in the get-tough-oncrime agenda, says Chaimowitz, who is also past-president of the Canadian Academy of Psychiatry and the Law. "When you start arresting and incarcerating people for petty offenses you're going to pick up more individuals with mental illness; it does skew towards incarceration of the mentally ill. ... At the end of the day, I don't think it will do anything but increase the incarceration of the mentally ill."

As a corollary, the conditions of confinement essentially increase the rate of mental illness, Sapers notes. "There is an increase in the population of those who are becoming or developing mental health problems while incarcerated. This seems to be related to a whole host of conditions related to conditions of confinement."

Part of that is a function of overcrowding, which results in the practice of double-bunking. "We're simply incarcerating more people," Sapers notes. "There are approximately 1000 more offenders inside Canadian federal institutions over the last couple of fiscal years. We've seen a relatively large increase: the equivalent of two medium security institutions. But we haven't seen two medium security institutions open up. So they're being stacked in existing institutions."
As a consequence of that doublebunking, "we're seeing more mental illness because the conditions are worsening," Sapers adds. "You're fitting more people into already crowded facilities; you're creating negative conditions of confinement, which does have an impact on people's mental health."

That will likely continue in the future. As of March 2012, the national rate of double-bunking was $17.18 \%$, representing over 2300 inmates, an increase of roughly $33 \%$ over the number who were double-bunked in March 2011 (www.oci-bec.gc.ca/rpt/annrpt /annrpt20112012-eng.aspx\#s4).

The government is hopeful, though, that the trend will be reversed as the construction of new facilities is completed. Roughly 2700 new cells are currently being constructed.

The question, though, is whether Canada is now caught in what Sapers calls the "gap between when policy changes and it creates new burdens on the system and when the system has the capacity to respond," or whether there are far more systemic problems with Canada's approach to the provision of health services for the incarcerated. Nathan Stall MD, Toronto, Ont.

CMAJ 2013. DOI:10.1503/cmaj.109-4390

\title{
Agony behind bars
}

\section{M} ost Canadians are familiar with the shocking video footage that was presented in a coroner's court in 2012 as part of an inquest into the Oct. 19, 2007 selfstrangulation of teenager Ashley Smith inside a solitary confinement cell at the nation's only federal women's prison, the Grand Valley Institution for Women in Kitchener, Ontario.

It's hard to imagine that any of the verbal evidence to be presented this month at the inquest will be more plaintive than the chilling "how can it get worse?" Smith asked as Royal Canadian Mounted Police bound her wrists together with duct tape during a 2007 prison transfer between Saskatoon, Saskatchewan and Montréal, Quebec.
But the fact is that for thousands of other mentally ill inmates in Canada's prisons, experts say, things are altogether likely to get much worse.

While the deinstitutionalization movement and the "get-tough-oncrime" agenda of Prime Minister Stephen Harper's government have contributed to the rising number of mentally ill people who are incarcerated (www.cmaj.ca/lookup/doi/10.1503 /cmaj.109-4390), that doesn't begin to account for the effects of deficiencies in care provided to the mentally ill who are incarcerated.

The critics charge that correctional facilities are no form of therapeutic haven for the afflicted and that once in prison, mental health needs typically go unde- tected or untreated. Mentally ill inmates are left to decompensate psychiatrically.

Or as Correctional Investigator of Canada Howard Sapers notes: "Many mentally disordered inmates do not manage well in a prison environment."

"Some manifest symptoms of their illness through disruptive behaviour, aggression, violence, self-mutilation, suicidal ideation, withdrawal, refusal or inability to follow prison orders or rules," Sapers earlier stated in his 20112012 report (www.oci-bec.gc.ca/rpt /annrpt/annrpt20112012-eng.aspx\#s4). "Within corrections, these symptoms of mental illness are often misunderstood as manipulative or malingering behaviour, and are regularly met by a range of inappropriate responses including disci- 
plinary sanctions, transfer to higher security institutions and separation from general population. This state of affairs is especially prevalent in the maximum security and multi-level institutions where it is not uncommon for more than half of the offender population to be receiving institutional mental health services and/or presenting some degree of mental health dysfunction."

Sapers is blunt in his assessment of the federal government's provision of mental health care for inmates. "The Correctional Service of Canada is responsible by law for being health care providers for federally incarcerated inmates, and they are falling short in meeting that requirement for the provision of mental health services."

For its part, the Correctional Service of Canada indicates that it has made several multi-million dollar investments into mental health care as part of its 2007 Comprehensive Mental Health Strategy (www.csc-scc.gc.ca/text/pblct/lt-en/2007 132-1/2-eng.shtml). That initiative was structured around five core components:

- Voluntary intake screening and assessment for mental illness

- Primary mental health care within correctional facilities

- Intermediate care in an "accommodation unit" where offenders "can still work on their correctional plan, but have the treatment and support they need to manage their illness"

- Intensive care regional treatment centres for offenders with acute mental disorders, such as schizophrenia, and

- Transitional care that would "ensure continuity of care once they [offenders] left the institution."

How effective has it been over the course of five years?

A "mixed report card," Sapers says. "It's doing a better job than ever of assessing new admissions to penitentiaries. There's a new computerized program that screens for mental health issues and needs and creates a record of mental health issues of inmates."

But the progress stops there, he adds. "Where things begin to go off the rails is in implementing the strategy and responding to those assessed needs."

Major gaps in the treatment of acutely mentally ill offenders remain, Sapers says. "Those offenders with the most sig-

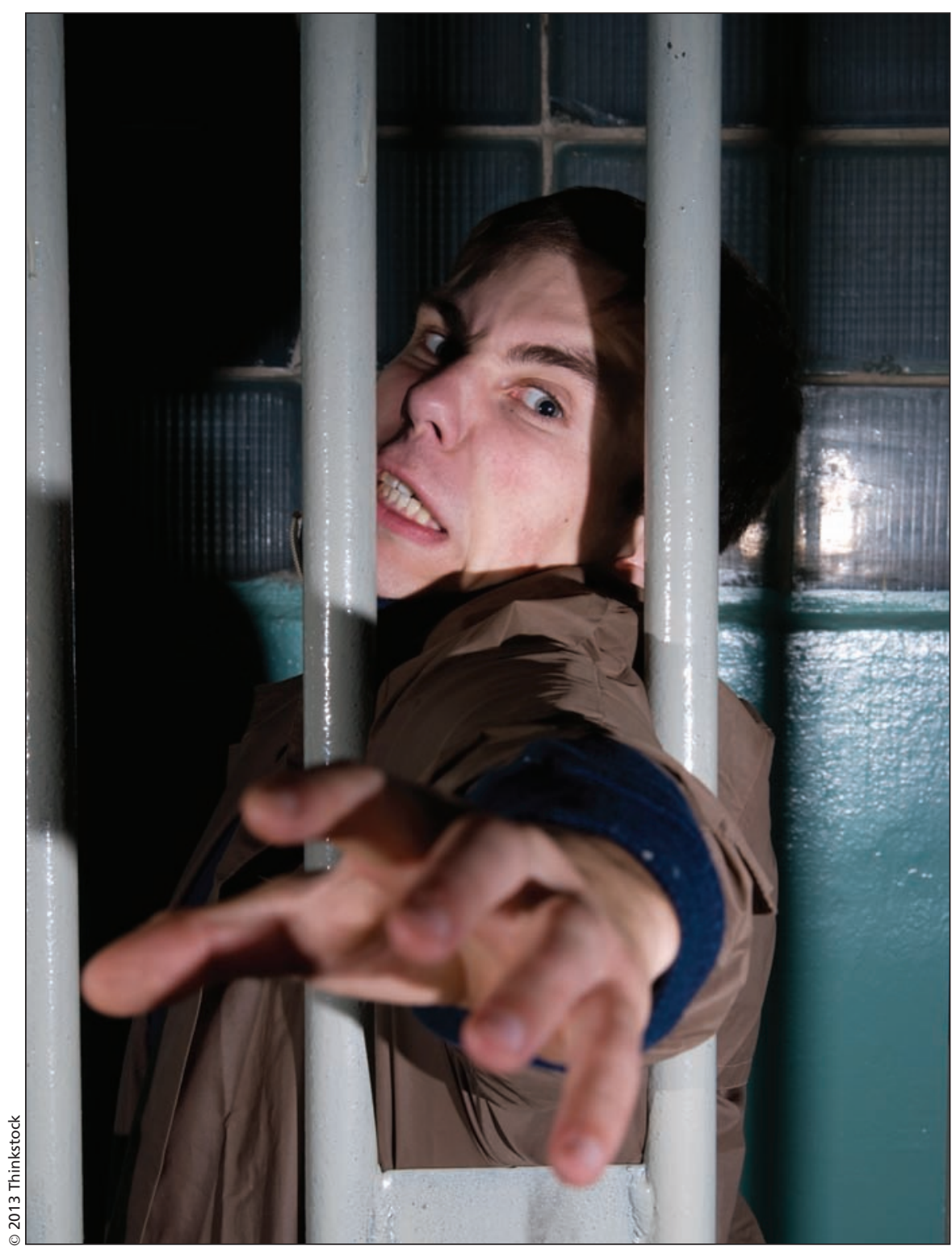

Some inmates with mental health problems "manifest symptoms of their illness through disruptive behaviour, aggression, violence, self-mutilation, suicidal ideation, withdrawal, refusal or inability to follow prison orders or rules," according to Correctional Investigator of Canada Howard Sapers.

nificant mental illness are not being able to access treatment beds and physician care, and increasingly are being held in higher security levels and segregation."

The setting itself is an obstacle to treatment, says Dr. Graham Glancy, assistant professor of psychiatry and adjunct professor of law at the University of Toronto in Ontario, and one of a handful of Canadian psychiatrists who consult on mentally ill inmates in correctional facilities.

"You work in difficult conditions for a psychiatrist," he says. "Basically you're dealing with severe and persis- tent mental illness, in a setting where you don't have access to social workers and psychiatric nurses and family members for support. You have one foot in the door and you have to work on very small cues."

Psychiatrists are further handcuffed by rules governing treatment in correctional facilities, he adds. "You can't use coercive treatment under the Mental Health Act, meaning that you should not treat people against their will even if they're deemed incompetent. At the same time, hospitals haven't always been available to help out." 
At all times, security is the "number one priority," Glancy notes. The federal prisons themselves, are primarily staffed by "correctional officers who get some training and have some natural acumen in dealing with mental illness but they're not psychiatric nurses in psychiatric facilities. There's always going to be problems there."

Sapers concurs. "Often the first responders to these individuals in these medical crises are correctional officers as opposed to health care professionals. We will often see people who are acting out, being responded to as security issues rather than mental health issues."

But there's also a lack of professional expertise to provide quality mental health care at every level of need, Sapers adds.

"For those who are less acutely mentally ill, we're also seeing a lack of capacity. It's not uncommon to find as much as a $20 \%$ vacancy rate in psychology positions. And many of those psychology positions that are filled, are being staffed by people who are not registered psychologists."

Intermediate care, meanwhile, "has not been funded," Sapers adds. "There is only one facility in the whole country for women with mental illness. It's a 12-bed unit in Saskatoon [Saskatchewan] in an otherwise male facility."
There's also increased pressure on the system because of growing demands for mental health services within prisons. According to the Correctional Service of Canada, the proportion of offenders with mental health needs identified at intake doubled between 1997 and 2008. Wait times for services also lengthened. In British Columbia, for example, the average time for inmates certified under the Mental Health Act to be transferred to a forensic psychiatric hospital increased from 4.5 days in fiscal 2001/02 to 10 days in 2007/08 (Behav Sci Law 2009; 27:811-31).

Hardly surprising then, that there has been a parallel increase in self-inflicted injuries, with the number of such incidents having more than doubled over the past five years. According to the Correctional Service of Canada data, there were 822 incidents of self-injury in fiscal 2010/11, involving 304 offenders, including 54 suicide attempts (www.oci-bec.gc.ca/rpt/annrpt/annrpt 20112012-eng.aspx\#s4).

The growing incidence of such selfharm disturbs Sapers. "Every day I receive reports on people who are self harming themselves, and responded to by emergency response teams with pepper spray and left in restraints for hours," he says. "Not the most therapeutic responses."

Little wonder then that the suicide rate among the federally incarcerated is seven times higher than the national per capita average. In the system's 2010-2011 reporting period used by Sapers, there were four completed acts of suicide, with three of those occurring within segregation cells. For 2011-2012, that doubled to eight suicides (www.oci-bec.gc.ca/rpt /annrpt/annrpt20112012-eng.aspx\#s4).

That broadens the stakes, says Ivan Zinger, executive director of the Office of the Correctional Investigator of Canada. "Addressing the criminalization and warehousing in penitentiaries of those who suffer from mental illness is not simply a public health issue, it's a human rights issue." - Nathan Stall MD, Toronto, Ont.

\section{CMAJ 2013. DOI:10.1503/cmaj.109-4391}

Editor's note: Second and third of a multipart series on health in the hoosegow.

Part I: Health and hard time (www.cmaj.ca/lookup/doi/10.1503 /cmaj.109-4389).

Next: Black eyes and barriers

\section{More news online}

Gender perceptions on eating disorders slow to change: Consider these two words: eating disorder. What image springs to mind? A father of three who works in the oil industry? A male lawyer? A young man with muscular shoulders on a college wrestling team?

Chances are, these were not the people you first associated with an eating disorder. Most likely, you thought of a very different type of person.

"A young adolescent girl from a relatively privileged background," says Leigh Cohn, author of Making Weight: Men's Conflicts with Food, Weight, Shape \& Appearance. "That was the image because that was the type of person showing up for treatment. All the emphasis was on women."

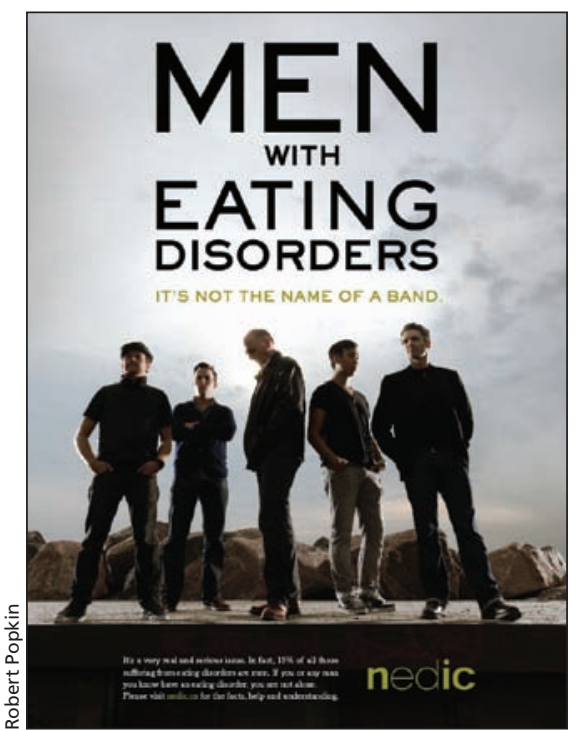

For many years, it was thought that men accounted for only about $10 \%$ of cases of eating disorders such as anorexia nervosa and bulimia. But this estimate, based on people in treatment, is now believed to be way off the mark. A growing body of research suggests as many as $25 \%$ of people with these conditions are male, and for binge eating, that increases to about $40 \%$.

Though a decade's worth of research indicates eating disorders in men are a bigger problem than imagined, the public perception that these are "female diseases" lingers. This certainly isn't helping to get more men to recognize they have a problem and need treatment, experts suggest especially considering the stigma already associated with eating disorders and the fact that men are less likely to seek medical treatment in general.

"Raising awareness is probably the most important thing. We have to 